\title{
The Cine-Tourist's Map of New Wave Paris
}

\author{
Roland-François Lack
}

As I write, a project is under way at New York University (NYU) to produce a map-based app of New Wave Paris as an educational tool for students and cinephiles. For cine-tourists too, I hope. This essay was researched and drafted as I imagined what a map of New Wave Paris might be like, without the expectation that it could so soon be realised. An earlier, broader project called Cinemacity gave indications as to what a more general cine-touristic app-map of Paris might look like, and in part this essay is informed by New Wave-related mappings to be found on that site. ${ }^{1}$ Overall, however, what follows are hypotheses and deductions based on old-school location hunting, with an old map in hand - more specifically, a 1962 'Indicateur des rues de Paris' (Fig. 6.1):

A necessary preliminary is to establish what we mean by New Wave - the when and the who. The broadest possible time frame stretches from the mid1950s to 1968. The filmmakers fall into five clear categories: (1) those associated with the Cahiers du Cinéma, not only the famous five (Chabrol, Godard, Rivette, Rohmer and Truffaut) but also several lesser-known critics turned filmmakers (among them Doniol-Valcroze, Givray, Kast, Moullet ... ); (2) the Left Bank group, chiefly Marker, Resnais and Varda; (3) the cinémavérité filmmakers, Rouch above all but also, for one film at least, Reichenbach; (4) the unaffiliated, making a first film in the New Wave period, in a New Wave

\footnotetext{
R.-F. Lack (ه)

University College, London, UK

(C) The Author(s) 2017

F. Penz, R. Koeck (eds.), Cinematic Urban Geographies,

Screening Spaces, DOI 10.1057/978-1-137-46084-4_6
} 


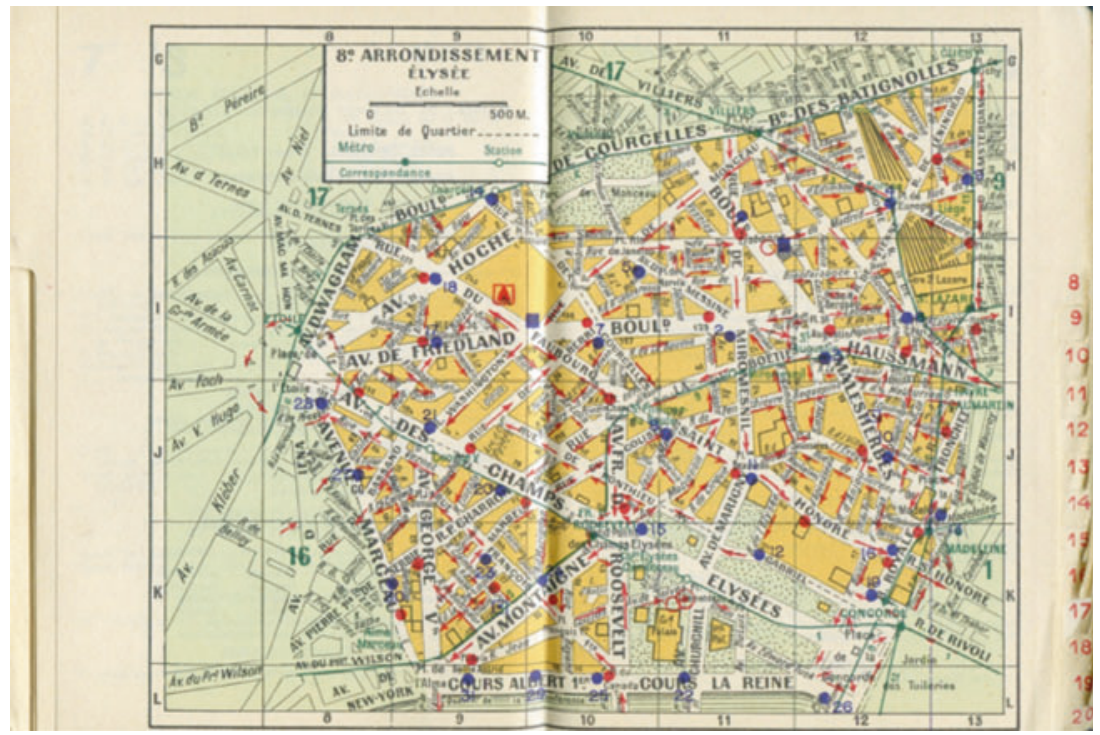

Fig. 6.1 Indicateur des rues de Paris (Paris: Editions L'Indispensable, 1962)

style, whether they go on to become distinct auteurs in their own right or are assimilated into mainstream filmmaking (Aurel, Bénazéraf, Cavalier, Demy, Enrico, Gilles, Jessua, Lelouch, Pialat, Pollet ...) and (5) filmmakers with reputations established independently of the New Wave who make New Wave or para-New Wave films in this period (Astruc, Baratier, Leenhardt, Malle ... ). From the work of these filmmakers in this period, we can constitute a corpus of about 60 films in which Paris is a location.

Writing of Les 400 coups, Tom Conley has established how important are the maps in the film to our thinking about the film cartographically: 'Few cities and few films are riddled with maps as much as Paris in Truffaut's first feature' (Conley 2007, p. 142). Five of these maps are of Paris, but they are background features in the street, in the métro, or in a police station, and no one in the film looks at them. Or almost no one. It takes the close scrutiny of a cine-cartographer to find significance in these background details:

In the depth of field are seen an older person and a child toying with an electronic metro-map that shows its user (who pushes on the button by the place-name of 
the appropriate destination) the best itinerary available. Like an electronic toy, it allows the older man and the boy to take a virtual voyage by following the illuminated dots of a broken zigzag of lights. (Conley 2007, p. 152)

The route that the electronic map proposes to the older man and child is along ligne 1 from Franklin D. Roosevelt station, where they are, to Vincennes. That itinerary, marked out in points of light, is emblematic of at least one kind of plotting that informs this essay. I would have liked to find other instances to illustrate other kinds of plotting but, quite remarkably, this one scene, embedded in the background of Truffaut's film, is the only instance I have found in New Wave cinema where we too can read the map that someone is reading. The same electronic map at the same métro station appears in Adieu Philippine, but we cannot see an illuminated itinerary on it. In Le Combat dans l'île the protagonist looks at a map of Paris as he plots an assassination (on the rue Réaumur), but we are not able to read the map with him (Fig. 6.2).

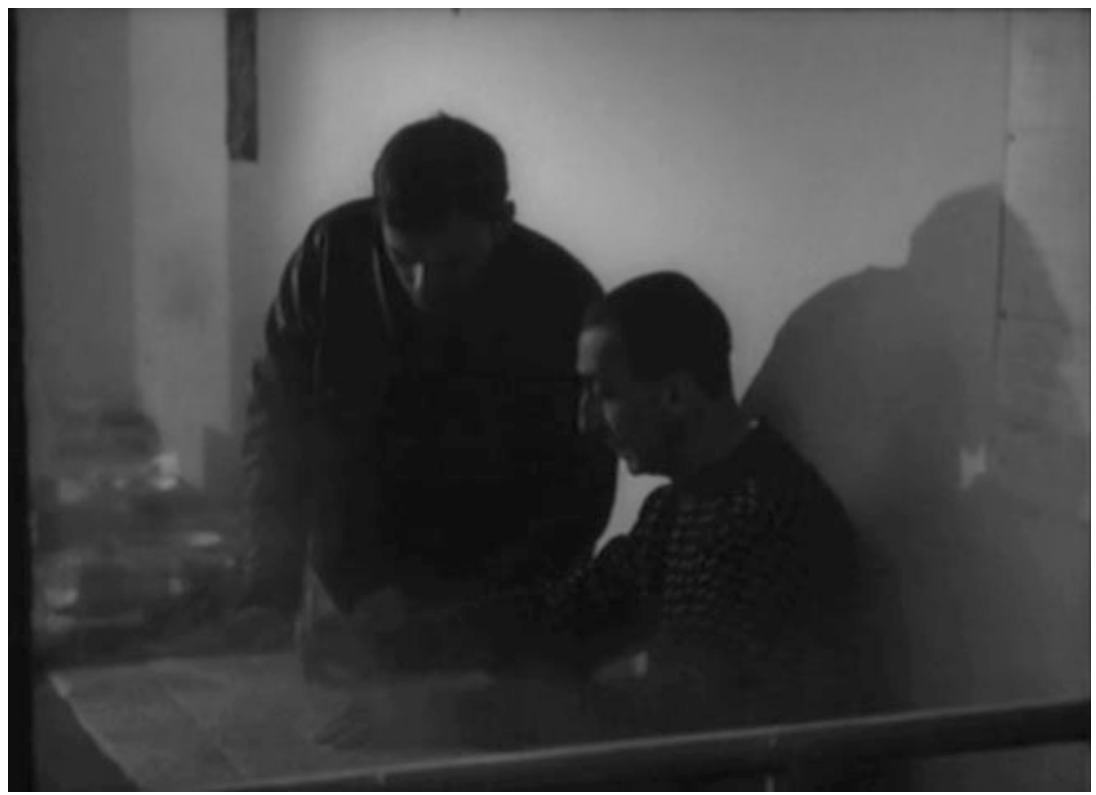

Fig. 6.2 Le Combat dans l'île (Alain Cavalier 1962) 
There are glimpses of Paris maps in the background of several New Wave films, and occasionally the map is drawn to our attention by the mise-en-scène, as here, with Anna Karina posing in front of a map for the super-8 camera of Michel Piccoli, a film within the film De l'amour (1964) (Fig. 6.3):

But this is the closest attention a New Wave film ever pays to a map of Paris. The significance of this strikes us when we see how often the map of Paris is scrutinised by New Wave filmmakers as soon as the New Wave is over, in, for example, Godard's Vladimir et Rosa (1970) and France tour détour (1977), Rouch's Petit à Petit (1971), Rivette's Out I (1971) and Le Pont du Nord (1981), Chabrol's Nada (1974) and Varda's L'une chante l'autre pas (1977). Guy Gilles's Au pan coupé (1967), already in manner a post-New Wave film, includes one moment of close map reading (Fig. 6.4):

The maps of Paris in New Wave films are, then, of no help in producing a map of New Wave Paris. No map in the film is a map of the film. Maps of

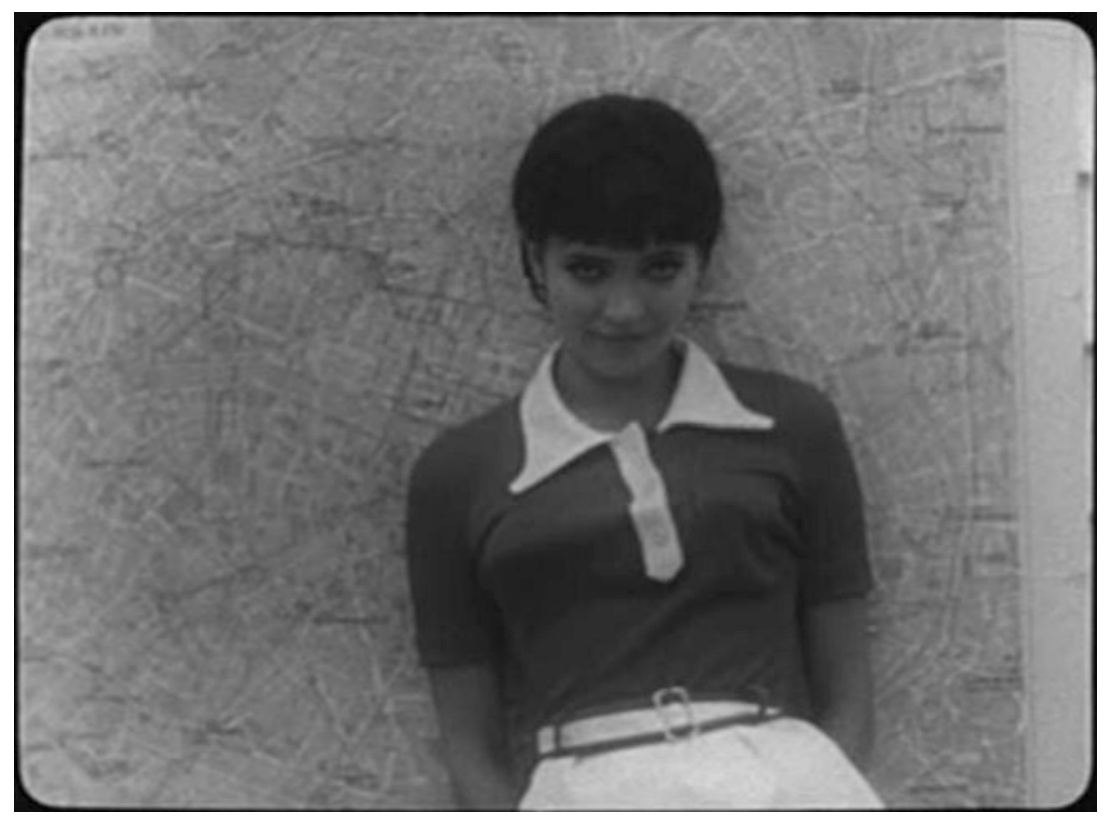

Fig. 6.3 De l’amour (Jean Aurel 1964) 


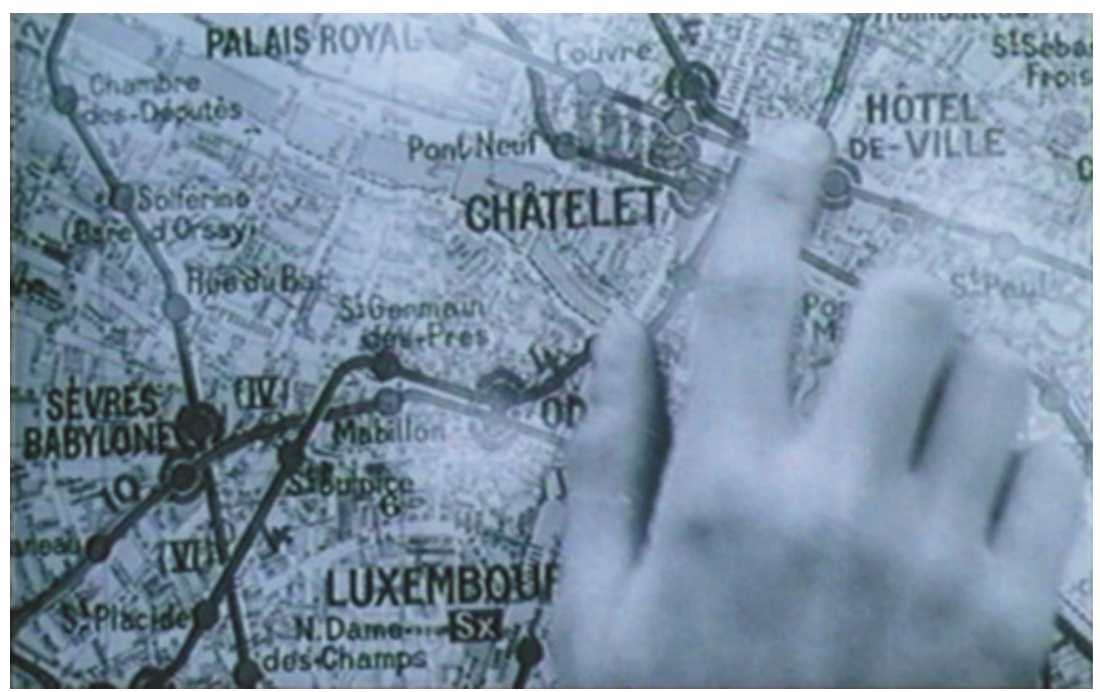

Fig. 6.4 Au pan coupé (Guy Gilles 1967)

New Wave films will have to be produced, one by one, and then laid one on top of the other to produce an aggregate map of New Wave Paris. The map will bring together all Paris locations in New Wave films, without preconceptions as to what is typical. Art galleries, bookshops, cafés, cinemas, hotel rooms and swimming pools may be typically New Wave places, but they will be marked on the map no differently from the more unexpected locations of New Wave Paris: an abandoned printworks (Les 400 coups), a travel agents' ( $A$ bout de souffle), a youth centre (Paris nous appartient), a hat shop (Cléo de 5 à 7), a zoo (Les Bonnes Femmes) and so on.

This simple map made of superimposed maps would reveal two things straightway: which parts of Paris belong to the New Wave and which do not. Franco Moretti asks a question of literary maps: what do they allow us to see? One of his answers identifies the kind of thing our map should show of New Wave Paris: 'its peculiar geometry, its boundaries, its spatial taboos and favourite routes' (Moretti 1998, p. 5). Of course we do not need a map to tell us that a favourite route of New Wave cinema is the avenue des Champs Elysées, a high-intensity location, with at least 20 films crowding into the vicinity of the Cahiers du Cinéma offices at no. 146. But the map would also show us points of lesser concentration that we might 
otherwise miss. We would note that Montmartre is visited less often than Montparnasse, the Jardin du Luxembourg more often than the Parc Montsouris, that the Pont des Arts is crossed more often than the Pont de Bir Hakeim. Belleville and Ménilmontant, recurrent locations in French cinema since 1905, appear on the map as subject to a spatial taboo. Only one New Wave film, a short by Jean Douchet called Le Mannequin de Belleville, explores that terrain explicitly, and does so precisely to highlight the incongruity of a New Wave film in an old school locale. ${ }^{2}$

The information regarding distribution provided on our map would be skewed by including single-locale films such as Le Mannequin de Belleville or, for example, Jean Rouch's 'Gare du Nord', one of the six parts of Paris vu par...(1965). Of the seven locations signalled in the film's section titles, the other six had already been visited by other New Wave films, strengthening the impression that the Paris seen in Paris vu par... is New Wave Paris: 'Saint Germain des Prés' (see Le Signe du Lion), 'Rue Saint Denis' (see Une femme est une femme), 'Place de l'Etoile' (see Paris nous appartient), 'La Muette' (see La Peau douce), 'Montparnasse' (see Cléo de 5 à 7 ) and 'Levallois' (see Vivre sa vie). But the Gare du Nord area, like Belleville, is off the New Wave's track. The rue Mouffetard in Varda's single-locale film Opéra-Mouffe appears again in Rohmer's Le Signe du Lion; the Jardin du Luxembourg in Godard's Charlotte et Véronique appears again in Rouch's La Punition, but the two or three streets around the Carrefour Villiers that we see in Rohmer's La Boulangère de Monceau, are not, as far as I can tell, seen again in a New Wave film.

These single-locale films are all shorts, logically enough since a short time frame usually constricts a film's movements, and it might be better to exclude shorts from our map, but then we would lose a film like Les Surmenés, which visits ten different Paris locations in 19 minutes, and we would not solve the problem of a feature such as Une femme est une femme, which is more or less confined to a small stretch of the grands boulevards and a part of the rue du faubourg Saint Denis. It would be better to include all Paris New Wave films, but to privilege in our interpretation those places where two or more films come together.

These reference points on the map, where two films are plotted onto the same place, are of low intensity but great significance, inviting us to read the two films together, an intertextuality signposted by the recurrent location. An extreme example is when Cavalier's Le Combat dans l'île checks into the same hotel used 2 years before by Godard in $A$ bout 
de souffle, the Hôtel de Suède, indeed occupies the same hotel room. The collocation here is a claim made by Cavalier's film to New Wave credentials, alongside the borrowing of an actor (Henri Serre) and location (le moulin d'Andé) from Truffaut's Jules et Jim (1962).

Cavalier's topographical borrowings are devices for positioning his film vis-à-vis New Wave precedents - to the same end he borrows plot elements from Godard's Le Petit Soldat (1960) and includes a sequence with jump cuts. Our map would point to something similar in plotting two films onto the same stretch of the rue Quentin Bauchart, outside the same nightclub, le Grisbi. Chabrol's Les Bonnes Femmes (1960) stays on the street near the club entrance, but in Les Nymphettes (1961), announcing in the title its variations on Chabrol's theme, one-off New Wave director Henri Zaphiratos take us inside to witness an amateur's analysis of the art of striptease. Chabrol's film includes, in another club (La Villa on the rue Bréa), a striptease by professional artiste Dolly Bell, and later in Les Nymphettes we see the protagonist walk past the club in which that performance takes place.

The place de Clichy is one of my hypothetical map's points of high intensity, thanks to just this kind of intertextual collocation. In Les 400 coups (1959) Truffaut establishes the location's importance for the intertextualities of the Antoine Doinel cycle, returning there with Doinel in Antoine et Colette (1962), Baisers volés (1968) and Domicile conjugal (1970), but the place de Clichy also signifies for other New Wave filmmakers positioning themselves vis-à-vis Truffaut. Jean Eustache goes there with his two male protagonists in Les Mauvaises Fréquentations (1963), inviting us to read their loutish behaviour as an adult perversion of the innocent playfulness of the two boys in Truffaut's film. In L'Amour à la mer (1964) Guy Gilles actually has his protagonist meet a Doinel-like Jean-Pierre Léaud on the place de Clichy.

The intertextualities of New Wave cinema have many more conduits than just these topographical collocations. Its shared world is signified by a whole variety of recurrences, from motor vehicles (the same 1954 Cadillac in A bout de souffle and Les Bonnes Femmes) or mentions of Balzac (in Le 400 coups, Les Cousins and $A$ bout de souffle) to character names (Laszlo Kovacs in $A$ double tour and $A$ bout de souffle; Michel Poiccard in $A$ bout de souffle and Lola; Lola in Lola and L'Amour à la mer) or cameo roles (Chabrol in Paris nous appartient and Les Bonnes Femmes; Rivette in Paris nous appartient and $A$ bout de souffle; Godard in Le Signe du Lion, Paris nous appartient and $A$ bout de souffle). Nonetheless, the clearest 
indication that New Wave cinema evolves in a shared world are the locations shared on my hypothetical map. ${ }^{3}$

Some collocations come unburdened by intertextual baggage. Several places on the map of $A$ bout de souffle appear on the maps of other films, without it being possible each time to argue that those others are asking to be read against or through Godard's film. The sight of the boulevard des Italiens in Rozier's Adieu Philippine, of La Pergola café in Rohmer's La Boulangère de Monceau, of the MacMahon cinema in Dupont's Les Distractions, is not necessarily a sign that these films are in dialogue with $A$ bout de souffle.

Even where there is dialogue, it is not always intertextual. When Godard is on the place de Clichy for Bande à part (1964) his own voice-over expresses admiration for this part of Paris, a theme developed in his preface to Truffaut's La Peau douce: 'Clichy, the most beautiful place in Paris, François was convinced of that...' (Godard 1965, p. 6). When, in Une femme mariée, Godard films at Orly airport he is using topography to connect his story of adultery with Truffaut's in La Peau douce, for which Orly is also a key location, but Godard's preface to La Peau douce opens onto different territory, evoking the Paris he shared with Truffaut when they were younger. This brings to the fore the lived topography of those who made the films, their apartments, the cinemas and cafés they frequented, their places of work, etc. Should, then, these biographical sites figure on the map?

I would say not, and would propose a different map for those interested in the men rather than their works ('les hommes, pas les oeuvres', said Truffaut). Such a map could then include the cemeteries in which these filmmakers end up buried - Truffaut in Montmartre; Chabrol in the Père Lachaise; Demy, Marker, Resnais and Rohmer in Montparnasse.

If lived locations do feature on the map of New Wave Paris, it should only be those that find their way into the films. There are many of these, of course, since it is a New Wave trope that the filmmakers draw on their own lives as a material resource. It is Godard's own car, for example, that arrives at the end of $A$ bout de souffle; the family home in La Peau douce is Truffaut's own apartment. Just outside Paris, on a street in Neuilly-surSeine - allowing that our map of New Wave Paris includes the immediate suburbs - we would find collocated Chabrol's Les Cousins and Rivette's Paris nous appartient. The apartment building occupied by the protagonists of each film is the same, being the address of Chabrol himself, conveniently available as location for his own film and made available to 
Rivette for his (of which Chabrol was a producer). Chabrol's apartment in this building was, earlier, the location for Rivette's (1956) short Le Coup du berger.

With at least three films collocated in this one street, la rue des Dames Augustines, there is a strong argument for stretching the city's limits to include the immediate suburbs on our map. The suburb just to the north of Neuilly is explicitly included in the Paris observed in Paris vu par..., thanks to Godard's 'Montparnasse-Levallois', and a good number of New Wave films also cross the line into the suburbs: Le Signe $d u$ Lion goes to Nanterre (via Neuilly), Les Bonnes Femmes to Puteaux, A bout de souffle to Choisy-le-Roi, Tirez sur le pianiste to Levallois, Vivre sa vie to Versailles, Bande à part to Joinville, La Peau douce to Suresnes and so on. Pialat's New Wave essay-film L'Amour existe documents at least 20 different suburbs of Paris. An aggregate map of all these films would show the points of high and low intensity within Paris and, surrounding the city, a circle of suburban locations, all of equal importance to a reading of New Wave topography.

The benefit from including the suburbs is not just that we increase the number of destinations for the app-using visitor. Moretti distinguishes between seeing Balzac's Paris as a cluster of individual locations or as a matrix of relations (Moretti 2005, p. 54). Movement between city and suburb is one of the more obvious relational features on the map of New Wave Paris, whether thematised in the title 'Montparnasse-Levallois', visualised in the long walk taken from the centre of Paris to Nanterre in Le Signe $d u$ Lion, or, in Les Cousins, verbalised when a taxi driver at the Gare de Lyon tells a client who asks to go to 'Neuilly-sur-Seine' that he should just say 'Neuilly'. In reading the map of New Wave Paris I follow Moretti in seeing 'relations among locations as more significant than locations as such' (Moretti 2005, p. 55), but I am as much interested in the intertextual relations that 'locations as such' may reveal. This should be all the more apparent after we focus on one of the basic components with which this map is made: the map of an individual film.

As much as I want to treat each item in the corpus of New Wave Paris films equally, the prestige of a certain number of them, the canon, may lead us to privilege their locations as somehow more 'New Wave' than locations in non-canonical films. In Paris nous appartient, the view from the roof of the Théâtre Sarah Bernhardt over the place du Châtelet has become emblematic of New Wave Paris, but this particular part of the city, despite its centrality, has few markers on our map. ${ }^{4}$ In Cléo de 5 à 7 , the long sequence 
in the Parc Montsouris makes this the ideal location for a New Wave picnic, but without Varda's film no cine-tourist would think to go there.

When the Map of New Wave Paris is completed, all films will have been treated equally, and each of their locations will have its marker on the map. In the meantime, however, since only a few, mostly canonical, films have been fully mapped, an examination of how the map of an individual film signifies must fix on one of the following: A bout de souffle, Les Bonnes Femmes, Cléo de 5 à 7, Paris nous appartient, Les 400 coups, Le Signe du Lion, Vivre sa vie or Paris vu par.... Each of their maps signifies differently, and ideally we would examine each in turn, but for reasons of space we shall focus only on $A$ bout de souffle.

The map of $A$ bout de souffle is not a map of Paris. The film begins in Marseille, followed by a car journey from there to Paris. A map of New Wave France would show this journey alongside several others, in other films, whether between Paris and the Mediterranean (Adieu Philippine, La Baie des Anges, Bande à part, Pierrot le fou) or from the provinces more generally to the capital (Les Cousins, Une simple histoire, Paris nous appartient, L'Amour à la mer, Brigitte et Brigitte). For the latter the map might look much like Moretti's map of 'the drive from the provinces to Paris in nineteenth-century novels' (Moretti 1998, p. 94), allowing us to see clearly the significance of relations between these locations.

However, the difference between novel and film raises a formal problem that would complicate the plotting on our map, a complication that $A$ bout de souffle illustrates well. The fiction of the film tells us that the journey from Marseille to Paris goes via the Route Nationale 7, whereas anecdotal evidence about the shoot suggests that they filmed on the Route Nationale 6. Exact identification of the 20 or so locations that make up this journey would show which of the two highways it is, but in effect both will find themselves marked on the map, since we have no grounds for privileging reality over fiction when plotting a film's topography. The map of Truffaut's La Peau douce, for example, would have a marker at Reims, where 20 minutes of the film is supposed to take place, but there would be markers also at Versailles, Suresnes, Ville d'Avray and, within Paris, at the place de l'Odéon and the rue de Marignan, since these locations are all used to stand in for Reims. La Peau douce also disguises a hotel in Paris as a hotel in Lisbon. Films can disguise one place as another where novels cannot. Happily, for us, places in New Wave cinema tend to be what they say they are, especially within Paris. Locational literalism is above all a convenience, but it is also one of this cinema's claims to realism. 
A different aspect of cinematic topography comes closer to the topography of the novel. The map of a film need not be confined to the places it visits. All of the places remembered or envisaged in $A$ bout de souffle constitute what we can call its topographical imaginary. One of our maps of the film would be a map of Europe. 'Milano, Genova, Roma', says the protagonist Michel, as he plans his itinerary near the beginning of the film, and all the way through the film Italy represents escape, happiness, love. Those cities should be marked on the map, as should those where, according to Michel, women are not as beautiful as everyone says they are - Stockholm, Paris, London, Rome, Rio - as well as the two cities where the women are not so bad: Lausanne and Geneva.

Beyond Europe, the United States populates the film's topographical imaginary through accumulated artefacts and references: cars, films, music, novels, cigarettes, President Eisenhower and an American woman with an Italian name, Patricia Franchini. Michel says that he sold cars in New York. Patricia tells a story of her father promising to take her to Mexico. These places, and more, have their place on a map of the film.

Within Paris itself there is a topographical imaginary at work. When Michel and his Montparnassian associate are trying to think of a possible hideout, Patricia suggests a friend's place in Montmartre, and is told 'No, not Montmartre, we have too many enemies there.' This exchange presents Paris as a territorialised space, with demarcated zones of activity for different sets of criminals. Though he will eventually be killed in Montparnasse, Michel thinks he is safe there, at least from any Montmartre-based rivals. This spatial opposition is also a temporal one, a distinction between this new, New Wave crime film dated 1960 and the old school of 1950s French crime films, for which the criminal heartland of Paris was Montmartre.

The Paris map of $A$ bout de souffle, plotting actual rather than imagined locations, confirms that Montmartre is spatially taboo. It shows that activity in the film is concentrated in three areas: on and around the Champs Elysées, near Saint Michel and in Montparnasse. It also shows where else the film occasionally ventures - the place Vendôme, the Gare Saint Lazare and the boulevard des Italiens - and that it avoids not only Montmartre, to the north, but also the outer reaches of Paris to the west, south and east, though there would be extra-mural markers in the suburbs south-east of Paris, at Choisy-le Roi and at Orly airport.

The Montmartre-Montparnasse opposition is the most significant spatial relation in the Paris-centred map of this film. It is significant also in 
that the opposition is not shown - no one goes from one place to the other - but only told. The film's chief mode of connection between places in Paris is the journey, privileging the journey over the points of departure and arrival. To map these journeys would be as important as plotting the locations that they connect but, generally, these journeys are topographically incoherent. I have said that places in New Wave cinema tend to be what they say they are, but journeys like these are an exception. There are four within Paris, the least coherent of which goes from the quai de la Mégisserie to the rue Lord Byron via the rue Guynemer, the grands boulevards, the Cours la Reine and the rue Saint Denis. The only legible map of this journey would be a line from the starting point to the destination, which would be a map of the narrative event, rather than a plotting or ordering of the locations seen; it would not be a picture of the sequence. A topographical incongruity, the fact that the actual locations include places off-route, combines with a chronological incongruity, the editing together of those locations in an unfeasible order, including returns to locations already visited; the sum is an unmappable itinerary.

More exactly, the various incongruous locations passed in the course of each of these car journeys can be plotted as points on the map, but we could not join up the dots to produce a feasible itinerary. We can position ourselves at the junction of the rue de Vaugirard and the rue Bonaparte to reiterate Michel's observations on the house in which he was born (where Scott and Zelda Fitzgerald lived in 1928) and on the ugly modern building opposite, but we cannot do that in the course of a taxi ride along the route that Michel and Patricia would have taken. Other car rides in other films (Tirez sur le pianiste, Vivre sa vie) are similarly beyond reconstruction, as is a journey on the métro taken in Bande à part. ${ }^{5}$ On the other hand, Cléo's movements around Paris - on foot, by car and by bus - are topographically coherent and retraceable by the cine-tourist. In her own re-edition of Cléo de $5 \grave{a} 7$, Varda provides a map for that purpose, as well as a retracing of the itinerary by motorcycle.

It is not only students and cinephiles who may wish to position themselves in relation to the places of New Wave cinema. I have signalled already the intertextual impulse that leads to the collocation of films on the New Wave map. This impulse is felt beyond the time frame of the French New Wave, in particular by films that seek, nostalgically, to remember the New Wave. The Dreamers (2004) shows us the entrance to the Musée du Cinéma, as seen in Baisers volés, and brings there the star of Truffaut's film, Jean-Pierre Léaud, to reinforce the connection. Later, 
Bertolucci's protagonists run through the Louvre as did those of Bande à part, and the scene is intercut with matching shots from Godard's film. More subtle is the matching of a shot from $A$ bout de souffle, on the Champs Elysées in bright sunlight, with an entirely contrasting view of the rue Malebranche, at night in the rain. Here is the Hôtel de Senlis, where Bertolucci's young American is staying; the protagonist of Le Signe $d u$ Lion, an older American, attempts to get a room in this same hotel. There are, I suspect, other such deeply embedded memories of New Wave topography in The Dreamers.

The run through the Louvre is, on a small scale, a journey of sorts, one easily reconstructed in the film and, we can suppose, by cine-tourists. A similar reconstruction occurs in Pascal Aubier's Le Fils de Gascogne (1995), where the protagonist runs down the rue Campagne première, pretending to be shot in the back, just as Belmondo does at the end of $A$ bout de souffle. Like Bertolucci, Aubier intercuts Godard's film into his own, signalling that his film is mapped exactly onto Godard's. He also, in an earlier part of the sequence, maps his film onto a part of the itinerary in Cléo de 5 à 7 , following Cléo from the boulevard du Montparnasse, down the rue Delambre and onto the boulevard Edgar Quinet. Aubier's matching of his film to Varda's is less precise than with $A$ bout de souffle, occupying the same general space as the pretext but not, in this case, matching its camera positions.

The map of the itinerary in A bout de souffle, or of its retracing in Le Fils de Gascogne, is easy to draw. Belmondo begins outside no. 11 rue Campagne première and heads south towards the junction with the boulevard Raspail, where he falls and, eventually, dies. The cine-tourist, like the actor Grégoire Colin in Aubier's film, can follow exactly in Belmondo's footsteps, compensation of sorts for not being able to retrace his car journeys.

We are not obliged, however, to follow an itinerary just because we can. Positioning ourselves on the rue Campagne première can mean fixing on stages along the route, rather than staggering past them. In stopping at each stage we note that between numbers 21 and 23 is the entrance to the ominously named passage d'Enfer, the Pathway to Hell, a commentary on the protagonist's situation that escapes us if we follow the movement of the film. We note also, opposite, the building where artist Yves Klein had his studio at the time, bringing intermedial intertextuality into the topographical frame. ${ }^{6}$ Our counter reading of Michel's run towards death allows us to go in the other direction, following the path of a different New Wave protagonist, the 
woman in Marcel Hanoun's Une simple histoire (1959), who walks past the same places shown in Godard's film, but the other way. These two films are not in dialogue with each other, but their collocation still invites us to think about them together. The intertextual difference between these two uses of the same locale takes us back to the map of each film. The presence here of Hanoun's protagonist is just one stage in that film's long, almost unmappable itinerary around Paris that ends in a 'terrain vague', wasteland near a housing block in the suburbs. In contrast to the lack of narrative closure in Une simple histoire, $A$ bout de souffle has its protagonist stumbling down the rue Campagne première towards death or, as the map tells us, the Montparnasse cemetery.

As he runs down the street, Michel passes signifying sites that feed the film's intertextuality, be it symbolic, cinematic, art historical, urbanist or architectural. The fine example of early Art Deco architecture that Michel passes just before dying does not seem particularly significant; the camera barely notices it, and Michel certainly does not. But 2 years later, when in a taxi Cléo passes the spot where Michel falls and dies, she and Varda's camera both look at the building (by André Arfvidson 1910). Thirty-five years later, Aubier's camera also looks at the building. His character mimics exactly the behaviour of Patricia in A bout de souffle, on exactly the same street, but Aubier stages the scene in front of Arfvidson's building, whereas Patricia had been shot against a different backdrop. In following Godard down the rue Campagne première Aubier, like any good cine-tourist, cannot help but look around at the multiple marks of the street's history (Fig. 6.5).

In wanting to be in the place where a film has been, to walk down the same street, sit in the same café or just look at the same thing, the cine-tourist can seem very much like any other kind of tourist. The difference is, firstly, that films themselves behave like tourists, going where films have been before, consciously or unconsciously, and in so doing they intertextualise the map of the places they visit. Secondly, once the map allows one intertextual connection to be made, through collocation, it makes map reading a process of establishing further connections. The cine-tourist's pursuit of the topographical intertext becomes abyssal. How can we read the map of New Wave Paris without consulting the maps of non-New Wave Paris, the Paris of writers, painters and photographers, etc., but above all the Paris of filmmakers: Feuillade's Paris, Gabin's Paris, Gene Kelly's Paris, the Paris of New Wave filmmakers once the New Wave was over (see Rohmer and Rivette, especially). 


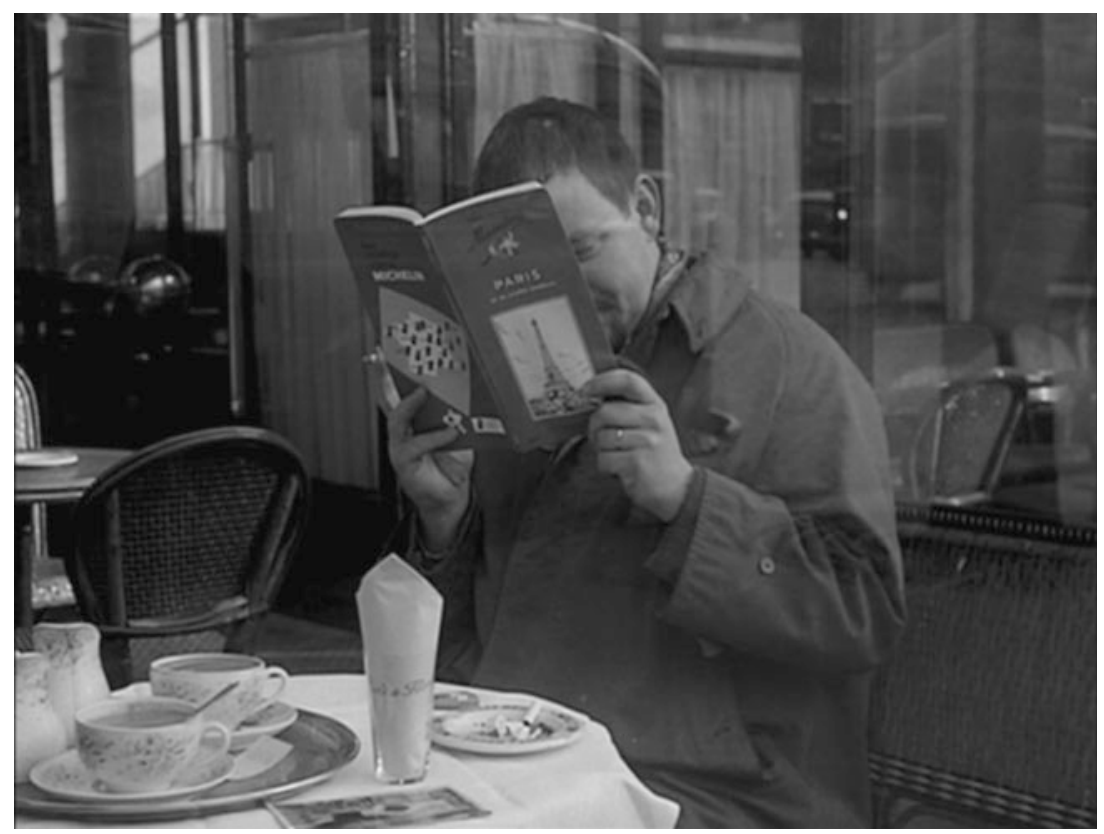

Fig. 6.5 Brigitte et Brigitte (Luc Moullet 1966)

At the risk of making what I thought would be a simple map infinitely more complicated, I now think that these should also be part of the map of New Wave Paris. In the meantime, work progresses on the first stage of the process, making the maps of each individual New Wave Paris film, one by one. ${ }^{7}$

\section{Notes}

1. The NYU app, created by Melanie Hackney, will be accessible via MapTheWave.com. Cinemacity, offering 'cinewalks in Paris' is here: http://cinemacity.arte.tv/en/.

2. Un coeur gros comme ca, L'Amour à la mer, Nadja à Paris and MasculinFéminin venture briefly into the Belleville area, and a sequence of Paris nous appartient was shot there but did not make the final cut.

3. I am grateful to Xiaoman Zhang for her insights into the shared world of the French New Wave. 
4. Nana's conversation with a philosopher in Vivre sa vie is in a café on the place du Châtelet, but otherwise there is nothing.

5. This impossible journey starts at Place de Clichy in the north west of Paris, then goes south to north, from Saint Michel through Château d'eau to the Gare de l'est, and ends up in the south east, at Liberté.

6. For insights into the art-historical associations of this street, see Shafto (2006).

7. Detailed identifications of New Wave Paris locations can be found here: http://www.thecinetourist.net/new-wave-paris.html.

\section{REFERENCES}

Conley, T 2007, Cartographic Cinema, University of Minnesota Press, Minneapolis.

Godard, JL 1965, 'Apprenez le François', in L'Avant-Scène du Cinéma no. 48, p. 6 Indicateur des rues de Paris, 1962. Editions L'Indispensable, Paris.

Moretti, F 1998, Atlas of the European Novel, Verso, London.

Moretti, F 2005, Graphs, Maps, Trees, Verso, London.

Shafto, S 2006, 'Leap into the Void: Godard and the Painter', in Senses of Cinema no. 39. Available from http://sensesofcinema.com/2006/cinema-and-the-pic torial/godard_de_stael/. [7 March 2015].

\section{Filmography}

A bout de souffle 1960, Godard, Jean-Luc. Adieu Philippine 1961, Rozier, Jacques.

L'Amour à la mer 1964, Gilles, Guy.

L'Amour existe 1960, Pialat, Maurice.

Antoine et Colette 1962, Truffaut, François

Au pan coupé 1967, Gilles, Guy.

La Baie des Anges 1963, Demy, Jacques.

Bande à part 1964, Godard, Jean-Luc.

Baisers volés 1968, Truffaut, François.

Les Bonnes Femmes 1960, Claude Chabrol.

La Boulangère de Monceau 1962, Rohmer, Eric.

Brigitte et Brigitte 1966, Moullet, Luc.

Charlotte et Véronique 1957, Godard, Jean-Luc.

Cléo de 5 à 7 1961, Varda, Agnès.

Le Combat dans l'île 1962, Cavalier, Alain.

Le Coup du berger 1956, Rivette, Jacques.

Les Cousins 1958, Chabrol, Claude. 
De l'amour 1964, Aurel, Jean.

Les Distractions 1960, Dupont, Jacques.

Domicile conjugal 1970, Truffaut, François.

The Dreamers 2004, Bertolucci, Bernardo.

Le Fils de Gascogne 1995, Aubier, Pascal.

France tour détour 1977, Godard, Jean-Luc.

Jules et Jim 1962, Truffaut, François.

Lola 1960, Demy, Jacques.

Le Mannequin de Belleville 1962, Douchet, Jean.

Masculin Féminin 1966, Godard, Jean-Luc.

Les Mauvaises Fréquentations 1963, Eustache, Jean.

Nada 1974, Chabrol, Claude.

Nadja à Paris 1964, Rohmer, Eric.

Les Nymphettes 1961, Zaphiratos, Henri.

L'Opéra-Mouffe 1958, Varda, Agnès.

Out 1 1971, Rivette, Jacques.

Paris nous appartient 1960, Rivette, Jacques.

Paris vu par... 1965, Douchet, Pollet, Rouch, Godard, Rohmer, Chabrol.

La Peau douce 1964, Truffaut, François.

Petit à Petit 1971, Rouch, Jean.

Le Petit Soldat 1960, Godard, Jean-Luc.

Pierrot le fou 1965, Godard, Jean-Luc.

Le Pont du Nord 1981, Rivette, Jacques

La Punition 1962, Rouch, Jean.

Les 400 coups 1959, Truffaut, François.

Le Signe du Lion 1959, Rohmer, Eric.

Les Surmenés 1958, Doniol-Valcroze, Jacques.

Tirez sur le pianiste 1960, Truffaut, François.

Un coeur gros comme ça 1961, Reichenbach, François.

L'une chante l'autre pas 1977, Varda, Agnès.

Une femme est une femme 1961, Godard, Jean-Luc.

Une femme mariée 1964, Godard, Jean-Luc.

Une simple histoire 1959, Hanoun, Marcel.

Vivre sa vie 1962, Godard, Jean-Luc.

Vladimir et Rosa 1970, Godard, Jean-Luc.

Roland-François Lack is Senior Lecturer in French and Film at University College London. He is the creator of The Cine-Tourist website, devoted to the relation between place and film, and is currently writing a monograph on the places of early French cinema. 